\title{
Terapi kelompok suportif untuk meningkatkan harga diri pada narapidana menjelang persiapan pulang
}

\section{Hana $^{1}$}

\begin{abstract}
Subjects in this study were convicts who are in the process of preparing to go home. Assessment is used by using interviews, observations and providing a Self Esteem Inventory Scale. The intervention given to the subject was to provide therapy to supportive groups consisting of eight sessions. The aim of this intervention is to increase selfesteem in convict. The results of the intervention showed good changes where before taking therapy the results of the self-esteem scale of the five subjects were at a low level but after attending therapy the results of the subject scale increased. Two subjects rose to moderate levels and three subjects rose to high levels.
\end{abstract}

\section{Keywords}

Supportive group therapy, self-esteem, preparatory convict go home

\section{Pendahuluan}

Menjadi tahanan maupun narapidana tentunya bukanlah harapan siapapun namun pada kenyataannya banyak sekali individu yang menjadi tahanan dan narapidana bahkan jumlahnya semakin banyak dari hari-kehari. Tidak menutup kemungkinan jumlah tersebut akan semakin bertambah seiring berjalannya waktu.

Setiap individu yang masuk ke dalam lapas mengalami perubahan status. Perubahan status yang mereka alami adalah hal yang tidak terelakkan. Sebelum masuk ke dalam lapas status mereka bermacam-macam mulai dari ibu rumah tangga, pegawai, pedagang, mahasiswa dan lain sebagainya namun ketika mereka sudah masuk ke dalam lapas maka status mereka berubah menjadi tahanan dan narapidana. Bukan hanya status yang berubah namun pola hidup yang mereka rasakan tentunya juga ikut berubah. Sebelumnya mereka dapat pergi kemana saja dan berkumpul dengan keluarga, namun kini mereka tidak dapat pergi kemanapun dan tidak dapat berkumpul dengan keluarga. Perubahan-perubahan yang terjadi secara tiba-tiba dalam hidup mereka tentunya berdampak pada kondisi psikologis yang mereka rasakan. Perubahanperubahan yang berdampak pada kondisi psikologis ini akan menimbulkan berbagai masalah psikologis seperti rendahnya harga diri, kecemasan dan depresi. Penelitian yang dilakukan oleh Juniartha et al. (2012) menyebutkan bahwa narapidana di Lembaga Permasyarakatan Wanita Denpasar mengalami penurunan harga diri.

Harga diri yang rendah ini apabila dibiarkan dan tidak diatasi maka akan beresiko mengalami gangguan yang lebih besar lagi seperti depresi. Perasaan-perasaan tersebut juga dirasakan para narapidana menjelang kepulangan.
Tidak semua narapidana merasa lega dan bahagia. Banyak diantara mereka yang merasa tidak siap menghadapi dunia luar dan merasa rendah diri berinteraksi dengan dunia luar terutama pada wanita. Harga diri akan sangat berdampak pada emosi individu dan perilaku di masa depan. Individu yang memiliki harga diri yang rendah maka akan sangat sulit mengambil keputusan dalam hidupnya bahkan individu dengan harga diri yang rendah dapat mengarah ke arah psikopatologi (Jacob et al., 2006).

Oleh karena itu tentulah sangat penting untuk menangani permasalahan harga diri rendah bagi narapidana karena apabila permasalahan harga diri tidak segera ditangani maka akan berdampak pada permasalahan lain seperti kemampuan interaksi sosial, kesehatan fisik, depresi dan pengambilan keputusan hidup (Townsend, 2013). Hasil penelitian sebelumnya menunjukkan bahwa terapi atau konseling yang diberikan secara berkelompok memberikan hasil yang positif untuk meningkatkan harga diri seperti penelitian yang dilakukan oleh (Townsend, 2013) dalam penelitiannya ia memberikan konseling kelompok kepada delapan perempuan yang terdiri dari beberapa sesi terapi menunjukkan perubahan yang positif. Penelitian serupa yang dilakukan oleh (Chao et al., 2006) Terapi kelompok yang diberikan pada lansia menunjukkan hasil bahwa terapi yang diberikan secara berkelompok terbukti dapat meningkatkan harga diri dan kepuasan hidup. Terapi kelompok yang diberikan pada penderita anorexia nervosa

\footnotetext{
1 Allsmart Jakarta

Korespondensi:

Hana, Allsmart Jakarta

Email: hanahana26882@gmail.com
} 
yang terdiri dari enam sesi mampu meningkatkan harga diri para anggotanya (Fleming et al., 2014).

Salah satu intervensi yang pernah digunakan untuk mengatasi problem psikologis harga diri rendah yaitu dengan menggunakan terapi kelompok suportif. Terapi kelompok suportif adalah terapi yang dilakukan dengan sekelompok orang yang memiliki permasalahan yang sama sehingga individu yang menjadi bagian dalam kelompok menyadari bahwa bukan hanya dirinya yang memiliki permasalahan dan anggota dalam kelompok tersebut dapat saling membantu satu sama lain, mendukung, memberi saran dan saling memberi motivasi (Corey et al., 2001). Terapi kelompok suportif yang dilakukan pada lansia di panti jompo menunjukkan hasil yang efektif dalam meningkatkan harga diri, depresi dan kualitas hidup (Hannah Patricia S. et al., 2015).Berdasarkan penjelasan di atas dan penelitian-penelitian sebelumnya maka dirasa tepat untuk memberikan terapi kelompok suportif pada kelima subjek yang memiliki problem rendahnya harga diri.

Beberapa narapidana yang memiliki masa tahanan hampir selesai yang berada di Lembaga Pemasyarakatan (LP) Wanita Malang memiliki harga diri yang rendah. Lima diantaranya memiliki harga diri dengan level rendah. Hal ini terlihat dari perilaku sehari-sehari dan perasaan yang mereka rasakan. Para narapidana merasa dirinya kecil, tidak berguna, dan tidak bermanfaat bagi orang lain. Berdasarkan hasil skala harga diri yang diberikan juga menunjukkan bahwa para narapidana memiliki harga diri pada level rendah. Ketakutan-ketakutan dan kecemasan yang mereka rasakan seperti ketakutan tidak mendapatkan pekerjaan setelah keluar dari lapas, cemas apabila tidak dapat diterima oleh keluarganya, pandangan negatif masyarakat mengenai dirinya dan cemas apabila tidak dapat diterima oleh masyarakat.

Para narapidana merasa harga dirinya rendah karena dipengaruhi oleh banyak faktor, diantaranya adalah kurangnya penerimaan keluarga dalam menghadapi kenyataan bahwa ada anggota keluarganya yang menjadi narapidana, stigma negatif di masyarakat mengenai mantan narapidana yang menjadikan mantan narapidana kehilangan kepercayaan diri untuk berinteraksi dengan dunia luar dan ketakutan-ketakutan yang mereka pikirkan mengenai kehidupan setelah keluar dari penjara.

Harga diri adalah aspek yang sangat penting bagi manusia, pada dasarnya individu memperhatikan berbagai hal tentang dirinya seperti siapa dirinya, bagaimana orang lain memandang dirinya, dan bagaimana citra yang harus ditampilkan di hadapan orang lain. Dalam konteks kesehatan mental harga diri juga merupakan suatu hal yang sangat penting. Individu yang memiliki harga diri yang baik akan memandang dirinya secara positif, ia akan lebih memandang pada kelebihan-kelebihan yang dimilikinya ketimbang pada kelemahan yang dimilikinya. Begitu pula sebaliknya apabila individu yang memiliki harga diri rendah maka akan terfokus pada kelemahan yang dimilikinya (Carr, 2001).
Kebutuhan dasar manusia adalah unsur yang sangat dibutuhkan oleh manusia agar terjadi keseimbangan psikologis maupun fisiologis. Motivasi manusia dibedakan antara kebutuhan dasar dan meta kebutuhan. Kebutuhan dasar (basic needs) lebih kepada kekurangan akan hal hal fisiologis sedangkan meta kebutuhan adalah kebutuhan untuk pertumbuhan. Kebutuhan dasar meliputi rasa lapar, rasa aman, harga diri dan sebagainya. Meta kebutuhan meliputi keadilan, kebaikan, keindahan, keteraturan, kesatuan, dan sebagainya. Kebutuhan dasar adalah kebutuhan akibat dasar pada umumnya lebih kuat dari pada meta kebutuhan dan tersusun secara hirarkis (Sarwono, 2002).

Kebutuhan dasar manusia dimulai dari yang mulai mudah hingga meningkat ketingkat yang lebih sulit untuk didapatkan. Urutan kebutuhan tersebut dimulai dari kebutuhan fisiologis, rasa aman dan perlindungan, rasa cinta memiliki dan dimiliki, harga diri dan aktualisasi. Dapat kita lihat bahwa harga diri menempati tingkat keempat dari lima kebutuhan dasar Maslow, hal ini menandakan bahwa kebutuhan akan harga diri merupakan hal yang cukup sulit untuk dicapai (Alwisol, 2004).

Harga diri adalah penilaian individu terhadap hasil yang dicapai, dengan cara menganalisis seberapa jauh perilaku individu tersebut sesuai dengan ideal self. Harga diri dapat diperoleh melalui diri sendiri dan orang lain. Aspek utama harga diri adalah dicintai, disayangi, dikasihi orang lain dan mendapat penghargaan dari orang lain. Harga diri rendah apabila kehilangan kasih sayang atau cinta kasih dari orang lain, kehilangan penghargaan dari orang lain dan hubungan interpersonal yang buruk (Sunaryo, 2004). Akan sangat berbahaya apabila individu lebih menekankan harga diri pada kemahsyuran eksternal, sanjugan, atau selebritas padahal sebagai individu seharusnya lebih menekankan pada kapasitas diri (Adair, 2008).

Terapi kelompok suportif adalah terapi yang dilakukan dengan sekelompok orang yang memiliki permasalahan yang sama sehingga individu yang menjadi bagian dalam kelompok menyadari bahwa bukan hanya dirinya yang memiliki permasalahan dan anggota dalam kelompok tersebut dapat saling membantu satu sama lain, mendukung, memberi saran dan saling memberi motivasi (Corey et al., 2001).

Teknik dalam terapi kelompok suportif diantaranya adalah (1) Eksternalisasi perhatian yaitu usaha untuk mengalihkan perhatian klien yang mengalami kecemasan atau depresi dengan jalan memberikan dorongan agar klien dapat memulai lagi aktivitas yang pernah disenanginya (terapi sosial, terapi syair, terapi gerak, terapi musik, terapi kerja). (2) Bimbingan yaitu prosedur pemberian pertolongan secara aktif dengan cara memberikan fakta dan interpretasi dalam bidang pendidikan, pekerjaan, hubungan social, dan bidang-bidang kesehatan. (3) Manipulasi lingkungan yaitu usaha untuk menyelesaikan problem emosional klien dengan cara menghilangkan atau mengubah unsur-unsur lingkungan yang tidak menguntungkan. (4) Meyakinkan kembali (reassurance) 
biasanya menyertai pada setiap sesi terapi, klien yang merasa ketakutan yang irasional perlu ketenangan dan dihibur. (5) Sugesti-prestis yaitu usaha terapis untuk mensugesti klien yakni memberikan pengaruh psikis tanpa daya kritik. (6) Pengakuan dan penyaluran yaitu dengan cara mengeluarkan isi hati kepada orang lain, pendekatan ini untuk mengurangi tekanan yang ada pada klien sebab dengan adanya pengakuan dan penyaluran maka segala rasa tertekan yang mengganjal dapat dilepaskan (katarsis). (7) Dorongan dan paksaan yaitu dengan memberikan reward dan punishment untuk menstimulasi perilaku klien sesuai yang diharapkan diantaranya dengan cara klien diberi tugas untuk melawan impuls yang menimbulkan neurotik, berusaha menghilangkan atau mengurangi intensitasnya sampai di bawah titik kritis. (8) Persuasi yaitu mendasari diri pada anggapan bahwa dalam diri klien mempunyai suatu kekuatan untuk proses emosinya yang patologis dengan kekuatan dan kemampuan ataupun dengan menggunakan common sense nya sendiri (Luborsky, 1984).

Pemilihan intervensi dilakukan berdasarkan masalah utama yang dialami oleh para narapidana persiapan pulang di Lembaga Pemasyarakatan Wanita Malang. Masalah utama yang subjek alami adalah dari hasil interview, observasi, dan pemberian skala harga diri menunjukkan para narapidana yang mengalami problem harga diri yang rendah oleh karena itu terapis memberikan terapi kelompok suportif.

Berdasarkan hasil penelitian-penelitian sebelumnya menunjukkan bahwa terapi kelompok suportif terbukti efektif untuk meningkatkan harga diri seperti penelitian yang dilakukan oleh Hannah Patricia S. et al. (2015) menunjukkan bahwa terapi kelompok suportif yang dilakukan pada lansia di panti jompo menunjukkan hasil yang efektif dalam meningkatkan harga diri, depresi dan kualitas hidup.

\section{Metode}

Terdapat lima partisipan yang diberikan intervensi. Mereka adalah penghuni lembaga pemasyarakatan berjenis kelamin perempuan. Metode asesmen yang digunakan dalam kasus ini adalah dengan menggunakan interview dan observasi. Interview dilakukan kepada subjek, teman, dan petugas lapas. Tujuan dari interview ini adalah untuk mengumpulkan data yang bermanfaat untuk menegakkan diagnosa. Observasi dilakukan pada saat di lapas dan saat wawancara. Tujuan dari observasi adalah untuk melihat ekspresi dan pola perilaku subjek. Selain itu terapis juga menggunakan skala harga diri yang dikembangkan oleh Coopersmith dengan alat ukur adalah Self Esteem Inventory Scale yang dimodifikasi oleh Maryatun (2011) yang bertujuan untuk mengetahui pada taraf mana harga diri yang dimiliki oleh subjek.

Adapun intervensi yang dipilih adalah terapi kelompok suportif. Terapi kelompok suportif adalah terapi yang dilakukan dengan sekelompok orang yang memiliki permasalahan yang sama sehingga individu yang menjadi bagian dalam kelompok menyadari bahwa bukan hanya dirinya yang memiliki permasalahan dan anggota dalam kelompok tersebut dapat saling membantu satu sama lain, mendukung, memberi saran dan saling memberi motivasi (Corey et al., 2001).

Intervensi ini terdiri dari beberapa sesi yaitu. Pra Terapi: Subjek diberikan skala harga diri untuk mengetahui pada taraf mana harga diri yang dimiliki oleh subjek. Sesi (1) Pembentukan terapi kelompok suportif. Sesi ini bertujuan agar para anggota saling mengenal satu sama lain, terbangunnya kepercayaan antar anggota kelompok dan membuat kesepakatan bersama mengenai peraturan dalam terapi. Sesi (2) Eksplorasi masalah. Pada sesi ini para anggota saling menceritakan permasalahan dan perasaan yang dirasakan sehingga para anggota dapat memahami dan merasakan bahwa tidak hanya dirinya yang mengalami permasalahan. Sesi (3) Menonton video. Pada sesi ini terapi memperlihatkan sebuah video yang bertujuan agar para anggota kelompok mengambil pelajaran dari video yang ditampilkan, para anggota termotivasi untuk mencoba hidup lebih baik setelah keluar dari lapas dan para anggota tidak merasa rendah diri. Sesi (4) Membangun kemampuan koping. Pada sesi ini para anggota saling memberikan masukan satu sama lain dalam menghadapi persiapan kepulangan dari lapas serta mendorong para anggota yang pasif untuk ikut serta memberikan pendapat dan masukan pada anggota yang lain. Sesi (5) Membangun motivasi untuk mewujudkan strategi menghadapi kepulangan. Para anggota dapat saling memberikan motivasi dan dukungan satu sama lain. Sesi (6) Pemberian sugesti-prestis. Usaha terapis untuk mensugesti klien yakni memberikan pengaruh psikis tanpa daya kritik. Disini terapis memberikan sugesti dan gambaran bahwa mereka dapat menjadi pribadi yang lebih baik dan tidak akan kembali ke dunia gelap yang pernah mereka jalani dulu asalkan mereka memiliki komitmen dan usaha yang kuat. Sesi (7) Pengakuan dan penyaluran yaitu dengan cara mengeluarkan isi hati kepada orang lain, pendekatan ini untuk mengurangi tekanan yang ada pada para peserta sebab dengan adanya pengakuan dan penyaluran maka segala rasa tertekan yang mengganjal dapat dilepaskan (katarsis). Disini terapis meminta para peserta untuk memilih masing-masing satu atau dua orang yang menurut mereka dapat dipercaya dan menceritakan perasaan yang mereka rasakan agar para peserta tidak merasa tertekan karena ada orang lain yang memberi masukan. Diharapkan setelah selesai terapi kelompok suportif para peserta tetap mengaplikasikan teknik ini agar para peserta tidak terbiasa memendam perasaan dan menyalurkan perasaan tertekan yang dirasakan. Sesi (8) Evaluasi dan Terminasi. Pada sesi ini terapis bersama para subjek mengevaluasi seluruh kegiatan yang telah dilakukan, mengevaluasi kemampuan para anggota dalam menghadapi persiapan kepulangan dan mengakhiri terapi kepada seluruh anggota kelompok. Pasca Terapi, subjek 
diberikan skala harga diri untuk mengetahui pada taraf mana harga diri yang dimiliki oleh subjek.

\section{Hasil dan Diskusi}

\section{Hasil}

Setelah mengikuti serangkaian proses intervensi yang diberikan oleh terapis dengan memberikan terapi kelompok suportif yang terdiri dari delapan sesi terapi menunjukkan perubahan yang baik. Perubahan ini dapat dilihat dari hasil skala harga diri, perilaku dan pemikiran yang diperlihatkan oleh para subjek.

Dari hasil skala harga diri yang diberikan kepada kelima subjek menunjukkan perubahan hasil yang baik pada para subjek. Sebelum melakukan intervensi hasil skala harga diri kelima subjek pada kategori rendah yaitu pada rentang angka 49-56 dan setelah subjek melakukan serangkain sesi terapi hasil skala harga diri para subjek menunjukkan peningkatan, dua subjek memperoleh peningkatan menjadi kategori sedang dengan rentang angka 82-83 dan tiga subjek menjadi kategori tinggi dengan rentang angka 101106. Hasil ini dapat dilihat lebih jelas pada tabel 1 .

Bila dilihat pada mean (rata-rata) hasil skala harga diri pre-test dan post-test menunjukkan kenaikan nilai. Sebelum intervensi diberikan hasil skala harga diri ratarata kelima subjek adalah 57 dan setelah intervensi diberikan hasil skala harga diri rata-rata kelima subjek adalah 94,6. Berdasarkan hasil tersebut maka dapat dikatakan bahwa terdapat kenaikan harga diri pada kelima subjek yang mengikuti terapi kelompok suportif. Hasil perubahan ini dapat dilihat lebih jelas pada tabel 2 .

Perubahan lain ditunjukkan oleh para subjek dari pemikiran, perasaan, dan perilaku para subjek. Sebelum mengikuti terapi para subjek merasa tidak siap dengan status mantan narapidana yang akan disandangnya setelah keluar dari lapas, merasa takut akan dikucilkan oleh masyarakat setelah keluar dari lapas, dan merasa diri tidak berguna dan tidak berharga lagi. Namun pemikiran dan perasaan itu mulai berubah, para subjek merasa yakin bahwa mantan narapidana bisa menjadi individu yang lebih baik, para subjek berpikir walaupun akan ada orang yang akan berbicara negatif mengenai dirinya namun para subjek memilih untuk tidak memperdulikannya dan akan membuktikan kepada orang lain bahwa mereka bisa sukses dan menjadi baik dan para subjek yakin bahwa mereka adalah manusia yang baik, dapat bermanfaat bagi orang lain dan bisa menjadi manusia yang sukses asalkan mereka memiliki niat dan usaha yang kuat. Selain itu mereka yakin bahwa mereka adalah orang yang berharga dan yang akan membawa diri mereka menjadi orang yang berharga atau tidak adalah diri mereka sendiri.

Setelah pemberian terapi, diadakan tindak lanjut yaitu setelah 1 bulan dengan mewawancarai petugas lapas menunjukkan bahwa subjek merasa dirinya berharga dan siap menghadapi kepulangannya.

\section{Diskusi}

Setelah mengikuti delapan sesi terapi kelompok suportif menunjukkan hasil bahwa terapi kelompok suportif dapat meningkatkan harga diri narapidana menjelang persiapan pulang. Dari hasil skala harga diri menunjukkan tiga subjek yang semula memiliki hasil pada level rendah meningkat menjadi tinggi dan dua subjek meningkat menjadi sedang. Walaupun hasil yang didapat masingmasing subjek berbeda namun kelimanya menunjukkan adanya peningkatan setelah mengikuti terapi kelompok suportif. Hasil yang berbeda antara subjek yang satu dengan yang lain dipengaruhi oleh beberapa faktor seperti faktor pengalaman hidup, usia, dan pandangan dalam menilai diri tentunya menjadi faktor yang menentukan harga diri yang dimiliki oleh individu.

Sebelum melakukan sesi-sesi terapi kelompok suportif, para subjek lebih menekankan dan memfokuskan diri pada penilaian dan pandangan orang lain terhadap dirinya dari pada penilaian dan pandangan diri sendiri. Padahal menurut Maslow (Adair, 2008) akan sangat berbahaya apabila individu lebih menekankan harga diri pada kemahsyuran eksternal, sanjugan, atau selebritas padahal sebagai individu seharusnya lebih menekankan pada kapasitas diri. Oleh karena itu pada terapi kelompok suportif ini para subjek diarahkan untuk lebih menekankan kapasitas diri yang dimiliki oleh para subjek dari pada memfokuskan pada penilaian orang lain. Ketika para subjek telah mampu menekankan harga diri pada kapasitas diri maka akan meningkatkan harga diri yang dimilikinya.

Pada dasarnya harga diri akan sangat berdampak pada emosi individu dan perilaku di masa depan. Individu yang memiliki harga diri yang rendah maka akan sangat sulit mengambil keputusan dalam hidupnya bahkan individu dengan harga diri yang rendah dapat mengarah ke arah psikopatologi (Jacob et al., 2006). Oleh karena itu setelah harga diri yang dimiliki oleh para subjek meningkatkan maka para subjek mulai dapat berpikir lebih jernih dan terbuka mengenai hal-hal apa yang akan mereka lakukan setelah keluar dari lapas dan memiliki rasa optimis untuk menjadi lebih baik.

Hasil ini sesuai dengan penelitian-penelitian sebelumnya yang menunjukkan bahwa terapi kelompok suportif dapat meningkatkan harga diri. Seperti penelitian yang dilakukan oleh (Hannah Patricia S. et al., 2015) menunjukkan bahwa terapi kelompok suportif yang dilakukan pada lansia di panti jompo menunjukkan hasil yang efektif dalam meningkatkan harga diri, depresi, dan kualitas hidup. Selain itu penelitian yang dilakukan oleh Fleming et al. (2014) menunjukkan terapi kelompok yang diberikan pada penderita anorexia nervosa yang terdiri dari enam sesi mampu meningkatkan harga diri para anggotanya.

\section{Kesimpulan}

Setelah mengikuti delapan sesi terapi kelompok suportif, hasil menunjukkan bahwa terapi kelompok suportif dapat meningkatkan harga diri narapidana menjelang persiapan 
Tabel 1. Perbandingan hasil pre-test dan post test berdasarkan skala harga diri

\begin{tabular}{lcccccc}
\hline \multirow{2}{*}{ No } & \multirow{2}{*}{ Nama } & Pre test & \multicolumn{3}{c}{ Post test } & \multirow{2}{*}{ Hasil } \\
\cline { 3 - 5 } & & Total score & kategori & Total score & Kategori & \\
\hline 1 & PN & 56 & Rendah & 82 & Sedang & Meningkat \\
2 & PR & 55 & Rendah & 83 & Sedang & Meningkat \\
3 & FR & 63 & Rendah & 101 & Tinggi & Meningkat \\
4 & LA & 62 & Rendah & 106 & Tinggi & Meningkat \\
5 & II & 49 & Rendah & 101 & Tinggi & Meningkat \\
\hline
\end{tabular}

Tabel 2. Perbandingan mean hasil pre-test dan post test berdasarkan skala harga diri

\begin{tabular}{lll}
\hline & Mean & Jumlah \\
\hline Pre test & 57 & 5 \\
Post test & 94,6 & 5 \\
\hline
\end{tabular}

pulang. Dari hasil skala harga diri menunjukkan tiga subjek yang semula memiliki hasil pada level rendah meningkat menjadi tinggi dan dua subjek meningkat menjadi sedang. Walaupun hasil yang didapat masingmasing subjek berbeda namun kelimanya menunjukkan adanya peningkatan setelah mengikuti terapi kelompok suportif.

Hasil dari program ini merekomendasikan kepada pihak terkait untuk mendorong peningkatan harga diri narapidana dengan berbagai agenda positif yang memberi ruang untuk merasakan citra diri positif. Hal itu antara lain kompetisi dan pertemuan untuk saling berbagi mengenai kekuatan diri. Sedangkan pihak-pihak yang terkait itu meliputi sipir, kejaksaan, kepolisian dan juga keluarga yang mendukung secara tidak langsung para narapidana.

\section{Referensi}

Adair, J. (2008). Kepemimpinan yang Memotivasi Aturan "lima Puluh-Lima Puluh dan Delapan Prinsip Utama Untuk Memotivasi. Penerjemah: Fairano. Jakarta : PT. Gramedia Pustaka Utama

Alwisol. (2004). Psikologi Kepribadian. Malang: UMM Press

Carr, A. (2001). Abnormal Psychology. Sussex: Psychology Press

Chao, S.Y., Liu, Y.H., Yen wu, C., Jin, S.F., Chu, T.L., Huang, T.S., Chu, T.L., Huang, T.S., Clark, M.J. (2006). The effects of group reminiscene therapyon depression, self esteem, and life satisfaction of elderly nursing home residents. Journal of Nursing Research, 14, 1, 36-45

Corey, M. S., Corey, G., \& Corey, C. (2001). Groups: Process and Practice. California: Brooks Cole.

Fleming. C, Doris.E \& Tchanturia.k. (2014). Self esteem group work for inpatients with anorexia nervosa. Advances in Eating Disorders: Theory: Research and Practice, 2, 1, 233240

Hannah Patricia S., Louise Margarrette R., Josking Oliver L., Denisse Katrina C., Justine Kali O. (2015). Supportive group therapy: Its effects on depression, self-esteem and quality of life among institutionalized elderly. International Journal of Medical and Health Sciences, 2, 5.

Jacob, D., Cronje, M.E. \& Payze, C. (2006). Low self esteem of psychotherapy patients: a qualitative inquiry. The qualitative report, 11, 1, 182-208.

Juniartha, I, G. N., Ruspawan, I, D, M., Sipahutar, I, E. (2012). Hubungan Antara Harga Diri (Self-Esteem) dengan Tingkat Sress Narapidana Wanita Di Lapas Kelas II A Denpasar. Jurnal Keperawatan. ISSN: 2303-1298

Luborsky, L. (1984). Principles of psychoanalytic psychotherapy. A manual for supportive expressive treatment. USA: Basic Books, Inc.

Maryatun. S. (2011). Pengaruh logoterapi terhadap perubahan harga diri narapidana perempuan dengan narkotika di lembaga permasyarakatan kelas IIA palembang. Tesis. Fakultas Ilmu Keperawatan Program Magister Ilmu Keperawatan Kekhususan Keperawatan Jiwa Depok.

Sarwono, S, W. (2002). Psikologi Sosial, Psikologi Kelompok dan Psikologi Terapan. Jakarta : Balai Pustaka.

Sunaryo. (2004). Psikologi untuk Keperawatan. Jakarta: Buku Kedokteran EGC

Townsend, Elissa. (2013). The effectiveness of group counseling on the self esteem of adolescent girls. Theses. Counselor Education Master's Theses. The College Brockport: State University of New York. 